\title{
Analyzing Malaise and Mobilization: The Effects of Media on Political Support and European Identity in Old and New Member States
}

\author{
WAQAS EJAZ
}

$\frac{\text { DE }}{\text { GE GRUYTER }}$

Politics in Central Europe (ISSN: 1801-3422)

Vol. 13, No. $2 / 3$

DOI: 10.1515/pce-2017-0002

\begin{abstract}
The recent financial crisis and the way it was handled by European Union (EU) received a great deal of media coverage, and since the media has a tendency to alter public opinion, it is safe to assume that it has affected some Europeans' attitudes towards the EU. In order to test that assumption, a model was built around the theoretical framework of "media malaise," and »political support«. It was found that the media certainly affected and shaped public opinion; however, study revealed that consuming media has not made people more cynical towards the EU. Based on secondary data analysis of Eurobarometer the study reveals positive relationship of media mobilization effect with European's political attitudes and identity.
\end{abstract}

Keywords: European identity, Eurobarometer, media malaise, media mobilization, media effects, political support

\section{Introduction}

The creation of the European Union (EU), a supranational organisation that aims to enhance continent-wide cooperation and unification, is an excellent example of political community-building. Bringing such a community into existence has, however, been a daunting task. Since its inception, the EU has undergone many transformations in order to earn the political support of the people and the legitimate right to govern Europeans (Fuchs 2011). Political support is crucial for any governing institution, but it was not until a 1975 report by Tindeman that the gap between citizens and institutions of the Eu- 
ropean Communities (EC) was first acknowledged and presented as a source of tension for further European integration (Ruchet 2011). That report paved the way for discussions among political elites about how to transform the EC into a supranational institution while pursuing policies that would ultimately allow citizens to identify themselves with the EC.

Following the Maastricht Treaty (1992), the EC became the EU, and Europe witnessed its transformation into an intergovernmental organisation with extensive capabilities and competencies. Binding decisions taken at EU level began to have an increasing impact on the lives of citizens of the member states and a stronger effect on distribution matters. The EU has since changed from being a predominantly economic institution to one that is more political, raising questions about its legitimacy and the democratic deficit in public and scientific debates (Majone 1998; Hix 2008; Scharpf 2009). These debates have addressed another dimension of European identity, inquiring into whether and to what extent Europeans require a "concomitant European identity to guarantee the democratic legitimation of the institutions of EU and its decision making" (Fuchs 2011: 28).

Today, two decades after the Maastricht Treaty, these debates are very much alive mainly as a result of the complex economic, political and social challenges being faced by the EU. This article does not, however, focus on the conceptual and political challenges for the EU. Instead, it argues that the collective sense of European identity is a form of political support which does not always rely on economic benefits and may also be affected by relevant media consumption. Additionally, I contend that the recent Eurozone crisis has had different impacts on the various indicators of political support in the different EU member states. In order to assess these variations, I classify these states into two groups. The first is comprised of all of the member states that were part of the EU before its biggest ever enlargement in 2004 while the second group consists of the countries that joined the Union as a result of that enlargement. This study, thus, views the pre-2004 members as "old" and the post-2004 enlargement members as "new" member states.

To lay the groundwork for this investigation, the following section discusses the theoretical framework against which this study is situated. I then turn to the important relationship between media consumption and European identity and review the relevant literature. In the remaining parts, I present my empirical research along with the results and a discussion of key issues.

\section{Theoretical framework}

\section{Political Support}

The persistent attempts of scholars to find points of comparison between the "form of governing institutions, and political culture" can be traced back to 
Aristotle (Klingemann 1999: 50). However, modern theorists have relied extensively on Easton's $(1965 ; 1975)$ concept of political support and related tenets when approaching this issue. Easton's concept is indeed one of the most useful analytic frameworks regarding political support since it distinguishes among support for a political community, for a regime and for authorities (Norris 1999). In explaining the differences among these three objects, Klingemann (1999) argues that a political community is a cultural object that goes beyond the particularities of any formal governing structures and represents the collective identity of the polity. In contrast, a regime is a basic framework for governance (Norris 1999) while political authorities are officials occupying government posts (Klingemann 1999). Table 1 sets out Fuchs's (2011) modified representation of Easton's political support framework.

\section{Table 1: Political support framework}

\begin{tabular}{|l|l|l|}
\hline Types of Political Support & Political Support Constructs & Political Support Sub-constructs \\
\hline $\begin{array}{l}\text { Political community } \\
\text { Sense of community (diffuse } \\
\text { support) }\end{array}$ & Identity & European identity \\
\hline $\begin{array}{l}\text { Regime } \\
\text { Legitimacy (diffuse support) } \\
\text { Trust (diffuse support) }\end{array}$ & $\begin{array}{l}\text { Legitimacy } \\
\text { Trust }\end{array}$ & $\begin{array}{l}\text { Satisfaction with European } \\
\text { democracy } \\
\text { Trust in EU institutions }\end{array}$ \\
\hline $\begin{array}{l}\text { Political authorities } \\
\text { (specific support) }\end{array}$ & $\begin{array}{l}\text { Evaluation of short-term } \\
\text { output }\end{array}$ & $\begin{array}{l}\text { Evaluation of the national and } \\
\text { European economies }\end{array}$ \\
\hline
\end{tabular}

Note: The first two columns are adopted from Fuchs (2011) while the sub-constructs in the third column are used in the current empirical analysis. These sub-constructs have been chosen because of their similarity to the political constructs described by Easton (1965) and their applicability to the selected datasets.

As this table makes clear, Easton (1965) distinguishes the political support required by the three objects into two types: diffuse and specific support. Diffuse support refers mainly to the political community and regime; it does not focus on the performances of any particular components but rather considers the system as a whole (Fuchs 2011; Beaudonnet - Di Mauro 2012). As Easton (1975) explains, diffuse support concerns "what an object is or represents [,] not what it does" (p. 444). As such, diffuse support for a political community manifests in a "sense of community" and a "we-feeling" or a "feeling of belonging together" (Easton 1965: 185). The related political construct is identity, which encompasses the idea of a "we-feeling". The current study understands this sense of collective identity as European identity and takes this as the main dependant variable in this investigation. 
As with the political community, Easton presents several political constructs that relate to the regime component. For regimes, these constructs are legitimacy and trust. Legitimacy "reflects the fact that in some vague or explicit way [, a person] sees these objects as conforming to his own moral principles, his own sense of what is right and proper in the political sphere" (Easton 1975: 451). In line with this description, I would suggest that the construct of legitimacy can be operationalised by way of the indicator "satisfaction with democracy". In contrast, trust is "stimulated by the experiences that members have of the authorities over time" (Easton 1975: 448). This investigation uses the indicator "trust in the institution of the EU" to measure trust in the regime as a predictor of diffuse support (Schäfer - Weber 2014).

The second type of support mentioned by Easton, specific support, refers to attitudes (or behaviours) that arise from an evaluation of authorities' actions (Beaudonnet - Di Mauro 2012). Additionally, specific support is based on the perceived rewards of short-term output (Fuchs 2011: 31). The related political construct concerns the evaluation of political authorities based on their short-term output. As such, this article argues that people's assessments of the economic situation can predict their evaluations of incumbents. To operationalise Easton's notion of specific support, I therefore include people's perceptions of the national and EU economies as indicators. Significantly, the national and EU economies are interdependent, and, thus, both are considered as indicators of specific support.

Having outlined the conceptual framework for political support, I need to turn to the importance of comparing old and new member states and state the rationale for grouping the different states as per their EU membership dates. Given Easton's model, it may be argued that diffuse and specific support are highly interdependent. This is based on the logic that specific support, i.e. a performance evaluation based on short-term rewards, provides all that is needed to garner long-term diffuse support. Keeping this in mind, I have divided the member states into two groups in order to assess the different indicators of diffuse support in each group. I have also assumed that the difference between diffuse support in the old member states before and after the crisis will be less marked than is the case for the new member states. This assumption accords with Easton's model, which suggests that diffuse support serves as a buffer against the erosion of incumbents' support during a crisis and is more stable over time than specific support (Wessels 2007). As such, diffuse support should have remained stable with no or only a slight change after the crisis in the old member states. In contrast, there would have been significant post-crisis variations among the new members.

In order to better situate the theoretical framework for this study, I turn next to the dependent variable, i.e. European identity. 


\section{European Identity}

Easton's (1965) notion of diffuse support for a particular political community is realised in the concept of European identity (Delanty 2002; Bruter 2005; Hooghe - Marks 2005). Since the Maastricht Treaty, this concept has played a central role in the debate on European integration and come to be seen as a separate dimension of political support since it is one of the main explanations for existing support for the EU (Hooghe - Marks 2004; McLaren 2005). There are several definitions of European identity available, but this article follows the reasoning of Herrmann and Brewer (2004), who have described the "cognitive, evaluative and affective meaning" of collective European identity on two different levels, thus providing a comprehensive understanding of the concept (2004: 6). Fuchs (2011) stresses the importance of the first of these levels, which consists of individuals' subjective assignment and affective attachment to a particular collective. In sociological theories, this affective attachment is referred to as a we-feeling or feeling of belonging together in a community (Easton 1965; Scharpf 1999; Luhmann 2017).

In this investigation, I view affective attachment as an indicator of self-assignment to and identification with the European political community and use these terms interchangeably. Here it is important to highlight that collective identity is part of Easton's political support framework and interdependent with the other political constructs in that framework. This research, however, deems European identity to be a dependent variable and aims to explore its relationship with media consumption as well as other political constructs within the framework, focusing on the time frame before and after the Eurozone crisis in the old and new EU member states.

It must be emphasised that European identity remains subject to various conceptual and methodological challenges. As such, despite the fact that it has been rigorously investigated and the subject of many publications, the concept lacks any unanimous definition and is used in many different contexts and for different purposes. European identity has been assigned various attributes such as "abstract" (Strath 2002: 388), "flexible" (Walkenhorst 2008: 4), and "fluid [and] hybrid" (Maier - Risse 2003: 29). All of these descriptors attempt to highlight some characteristic of European identity from a specific vantage point, but collectively they do not support any particular agreement about the concept. In fact, these diverging interpretations of identity have led some scholars to challenge the very idea of investing time and resources in identity research because, in their view, the concept is so imprecise and contradictory that it can mean "anything" and "nothing" at the same time (Brubaker - Cooper 2000:1).

Nevertheless, while identity in general and European identity in particular are - like all social sciences concepts - highly contentious, their investigation remains important. For this reason, researchers in the field are continuing to 
investigate these topics and reveal their varied manifestations, which are vital for explaining different theoretical and practical phenomena.

Returning to the main objective of this article, the following section reviews the literature on media and European identity and highlights its importance for the current research.

\section{Media and European Identity}

For the purposes of this inquiry, media refers only to the use of television to acquire EU-related information. This is primarily because of the widespread use of television compared to other media for gathering information on different political matters. Such extensive reliance on media is crucial for forming and affecting collective identities, as has been confirmed by scholars in various contexts (Schlesinger 1991; Fornas 1995; Silverstone 1999; Morley 2001; Bruch and Pfister, 2014). Georgiou (2006), for instance, states that "media...have become organized mechanisms of great significance for constructing identities in local, national and transnational contexts within modernity" (p. 11). Along the same lines, we may observe the European Broadcasting Union's assertion in 1993 that broadcasting was playing "a decisive role" in affirming collective identity in the newly formed Central and Eastern European democracies (quoted in Luce 1993). Similarly, Meech and Kilborn's (1992) case study of Scottish media concludes that the media contributes to "Scotland's self-perception as a nation" (p. 258). The impact of media is particularly important when it comes to distant and abstract issues that the population does not have direct experience with (Page - Shapiro 1992). European identity, a political construct based on diffuse support for a political community, is one such issue because it affects people's daily lives but remains abstract and at the mercy of the subjective perceptions of EU citizens (Vliegenthart - Schuck - Boomgaarden - De Vreese 2008). Since most Europeans learn about the EU through media, it is conceivable that the way people consume specific media sources on European matters also influences their subjective perceptions of the EU and eventually affects their European identity (Ceron 2015).

While there is a presumption that media consumption and identity are significantly related, research on the effects of this relationship in general and on European identity in particular remains "embryonic" with more empirical investigations needed to reveal how this affects people's political identities (de Vreese - Boomgaarden 2006: 421). In the same vein, Rittberger and Maier (2008) point out that with few exceptions, the literature on public attitudes to EU integration has thus far neglected the role of the media in affecting people's opinions about their European identity. Moreover, Müller and colleagues (2014) confirm that most media and identity researchers have concentrated on the present situation without examining the longstanding structures that might have led to it. In order to advance the scholarship on this topic, the current 
study, thus, examines the effects of media consumption on European identity, comparing the situation in different years so as to expose the long-term effects of media on identity. In what follows, I outline the conceptual bases for two different effects of media.

\section{The Effects of Media: Malaise and Mobilisation}

In considering the impact of media on political attitudes, various studies have focused on media consumption as an explanatory variable. One particular effect that has been examined - and which is also addressed in this study - is media malaise. The concept of malaise emerged in the literature when Kurt and Gladys Lang (1966) first connected the increase in news consumption with feelings of disenchantment with American politics. These scholars further argued that television broadcasts fueled public cynicism by over-emphasising political conflict and downplaying routine policymaking (Norris 2000). The effects of malaise were not, however, given much attention until Robinson (1976) coined the term "video malaise" to highlight the connection between a reliance on American television journalism and feelings of political cynicism, social mistrust and a lack of political efficacy. Robinson's (1976) research examined the assumption that the more time citizens spend watching television, the less political support they manifest. Since then, several research studies have addressed video malaise exclusively, focusing on the effects of TV consumption rather than media consumption in general.

The counter-argument to the media malaise thesis is also quite compeling. This argument claims that the media is not associated with malaise, but in fact has an opposite effect described as "mobilization" (Newton 1999: 580). Norris (1996: 2000), for instance, argues that while general TV-viewing is associated with apathy, attention to the news media is - contrary to the media malaise hypothesis - linked with positive indicators of civic engagement. Furthermore, research by Newton (1999) in the UK found that reading a broadsheet newspaper and watching a significant amount of television news were associated with having greater political knowledge, interest and understanding. Holtz-Bacha (1990) has demonstrated similar patterns linked to attention to the news media in Germany while Curtice, Schmitt-Beck and Schrott (1998) also reported positive findings concerning media consumption and political knowledge. In an exhaustive study, Bennett and colleagues (1999) found that trust in politics and trust in the news media go hand in hand, uncovering no evidence that news media consumption is related to political cynicism.

Building on all this research, the current study considers the arguments of both of the above schools of thought and seeks to explore the relationship between media consumption and European identity. To ths end, I consider the situation before and after the Eurozone crisis in different EU member states. 


\section{Hypotheses}

Based on the arguments that have been set out above and deduced from established theories, this section outlines five distinct hypotheses. The first (H1) specifically describes the political constructs of diffuse and specific support. The first part of this hypothesis assumes that the economic crisis triggered a change in political attitudes in both the old and new member states. A utilitarian explanatory model would suggest that the economic crisis in Europe changed the personal cost-benefit calculus for many citizens, who adapted their political attitudes accordingly (Schäfer - Weber 2014). Ensuing bad economic conditions would, then, have prompted a decline in political support (Eichenberg - Dalton 2007).

H1: Levels of all diffuse political support indicators declined in both member state groups after the Eurozone crisis

The second hypothesis posits that the Eurozone crisis resulted in a negative relationship between specific support and European identity. This hypothesis tests the idea that European identity - that is, a kind of diffuse political support for a community - is contingent on the receipt of economic benefits. In other words, it suggests that it is only when member states have a beneficial relationship with the European polity that their people develop a sense of belonging to the collective. According to this logic, the crisis made this relationship less profitable and therefore negatively affected the sense of collective identity in both the old and new member states. Furthermore, this hypothesis aims to establish the relationship between evalutions of national and EU economies and European identity.

H2: A negative relationship arose between specific support indicators and identity in both the old and new member states after the Eurozone crisis

The third hypothesis seeks to confirm Easton's thesis and establish the interdependence of diffuse support for the regime and the political community. The inference here is that political evaluations of a regime (see Table 1) have a profound effect on European identity. Moreover, this relationship is thought to be independent of any crisis or date of EU accession.

H3: Democracy and trust have a positive impact on European identity

The fourth hypothesis considers the media's effects on identity by drawing on the malaise concept. According to this thesis, people who are heavily exposed to TV news coverage become more cynical, have less trust in political institutions and are ultimately less positive about politics. This hypothesis attempts to ascertain whether the malaise concept rings true and in fact affects the sense of European identity.

H4: Using TV as an information source has a negative effect on European identity.

As we have seen, the counter-concept to video malaise is media mobilisation (Newton 1999), which asserts that media exposure is associated with trust rather than mistrust in political institutions. Based on this media mobilisation theory, 
my final hypothesis posits that people's main source of information is the media and that this access to a greater scope of information helps them to become more aware and empowered to align with or support a given political structure.

H5: The scope of information accessed through media consumption has a positive effect on European identity

In order to investigate these hypotheses, I carried out an analysis of secondary data. In the following section, I outline the design of this study and various data attributes.

\section{Study design}

The secondary data which form the basis of this study were obtained from four different Eurobarometer surveys $(63.4,65.2,80.1,82.3)$. These surveys were carried out in 2005, 2006, 2013 and 2014 respectively. The rationale for the choice of two different time frames was to expose changes in different types of political support before and after the crisis. It must be emphasised that while Eurobarometer surveys are conducted multiple times every year, not every survey is based on the same questions. My analysis therefore only included those surveys that contained all of the variables required to operationalise the relevant constructs.

As has been noted, my focus was on both the old and the new member states. The relevant classification was made based on the date of each country's EU accession. In particular, countries that became members as a result of the 2004 enlargement were considered new members while the pre-2004 EU members were treated as old member states. Three current members, Romania, Bulgaria and Croatia, did not join the EU as part of the 2004 enlargement, acceding instead in 2007 in the case of Romania and Bulgaria and 2013 in the case of Croatia. Because of their different accession dates, these three countries were not included in my analysis. The final classification of member states, thus, put France, Belgium, Germany, Greece, the Netherlands, Italy, Luxembourg, Denmark, the UK, Austria, Sweden, Finland, Portugal, Spain and Ireland in the old member states group. In contrast, the new member states group consisted of Cyprus, the Czech Republic, Estonia, Hungary, Latvia, Lithuania, Malta, Poland, Slovakia and Slovenia.

\section{Operationalisation of the variables}

\section{Dependent Variable}

The dependent variable in this study (European identity) was operationalised using the prompt "Please tell me how attached you feel to the European Union", with respondents being asked to apply a scale from 1 (not attached at all) to 4 (very attached). This prompt sheds light on the subjective identification of individuals with the collective and has been used to assess European identity in several studies (Bruter 2005; Fuchs 2011; Schafer - Weber 2014). 


\section{Independent Variables}

There were several independent variables in this investigation, and each one corresponded with a specific construct. The first variable related to media consumption and was tested using the question "When you are looking for information about the European Union, its policies, its institutions, which of the following sources do you use? 1 - Meetings, 2 - Discussions with relatives, friends, colleagues, 3 - Daily newspapers, 4 - Other newspapers, magazines, 5 - Television, 6 - Radio, 7 - The Internet, 8 - Books, brochures, information leaflets, 9 - Other, 10 - Never look for such information, not interested." Since the study is only interested in video malaise, I included only those respondents who selected "television" as an information source on European politics. This approach was further justified by the finding of many scholars that print media positively affect political attitudes (see, e.g., Newton 1999; Norris 1996) and malaise is mostly linked to television consumption.

The second independent variable referred to the effect of media mobilisation on European identity. This was operationalised using the question "To what extent do you think that you are informed or not about European matters?" Respondents were asked to evaluate their level of information using a 4-point scale: 1 - not at all informed, 2 - not very well informed, 3 - fairly well informed and 4 - very well informed. It is important to highlight the rationale for testing the media mobilisation hypothesis in this way. This question clearly does not itself afford the media any role in acquiring information, and its adequacy for gauging media mobilisation may, thus, be challenged. In response, however, I would argue that information about EU matters is usually acquired through the media, and as such, this question can be used to assess the effect of media mobilisation on political support.

Two additional indicators, satisfication with democracy and trust, were used to evaluate diffuse support for the regime. Feelings about democracy were measured using the question "How satisfied are you with the way democracy works in the EU?" with answers provided based on a 4-point scale: 1 (not at all satisfied) 2 (not very satisfied), 3 (fairly satisfied), 4 (very satisfied). Trust was assessed using the prompt "I would like to ask you a question about how much trust you have in the European Union. Please tell me if 1 (you tend not to trust) or 2 (tend to trust it)." Since both trust and democracy refer to a single political object, i.e. the regime, the two variables are highly correlated. To avoid multicollinearity in the ensuing regression analysis, I therefore created an index by calculating the mean result for the trust and democracy variables. Importantly, before the amalgamation of these two indicators, the satisfaction-with-democracy variable was recoded into two values, i.e. satisfied and not satisfied.

Based on the political framework set out by Easton (1965), specific support reflects evaluations of incumbents. In line with this approach, I used two indicators related to perceptions of the national and EU economic situations to 
measure specific support. I tested for these two indicators using the question "How would you judge the current situation in each of the following [locations]?" with the following options supplied for answers: 1 - very bad, 2 - rather bad, 3 - rather good and 4 - very good.

\section{Control Variables}

The analysis included a set of sociodemographic control variables. These concerned the age of the respondent; their political views based on their self-placement on a spectrum of 1 (Left) to 10 (Right); and their education (number of years spent in education).

\section{Data analysis}

Below I describe and explain the findings of the secondary data analysis which was conducted to test this study's hypotheses. Figure 1 provides a comprehensive picture of the different political support indicators among both groups of countries before and after the crisis.

Figure 1: Diffuse political support levels in both groups before and after Eurozone crisis

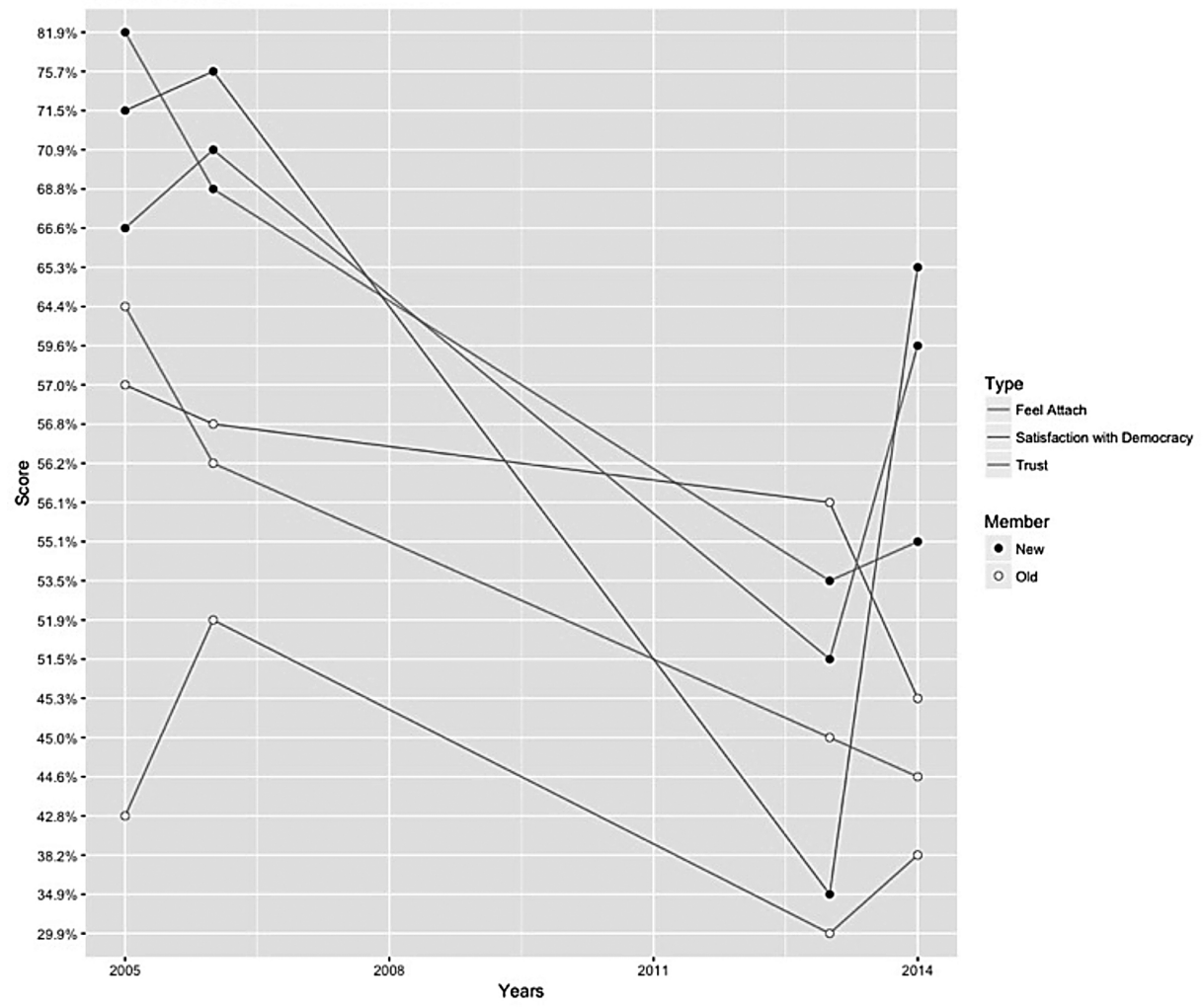


The first hypothesis had assumed that all forms of diffuse support for the EU declined after the Eurozone crisis and that this decline was independent of the classification of any given member state. Figure 1 confirms this assumption, showing a decline in all three indicators of political support after 2006, with support for the EU falling to its lowest level across all member states in 2013. It is also worth noting the sharp decline in the levels of EU attachment and satisfaction with democracy and trust in the EU across the new member states. A similar downward trend can be seen among the old member states though the difference between these political indicators before and after the Eurozone crisis was not as pronounced as it was among the new member states, especially between 2006 and 2013. Importantly, this picture began to change after 2013 when people again extended their support to the EU for its successful handling of the economic crisis. This strengthens the idea that political support is very much related to economic benefits.

In order to verify the assumptions of the other hypotheses, I conducted a multivariate regression analysis. The results are presented in the following table:

Table 2: Multivariate regression results

\begin{tabular}{|c|c|c|c|c|c|}
\hline & & 2005 & 2006 & 2013 & 2014 \\
\hline & R Square & $\begin{array}{l}0.17 * * * \\
(n=13803)\end{array}$ & $\begin{array}{l}.23 * * * \\
(n=15232)\end{array}$ & $\begin{array}{l}.12 * * * \\
(n=19229)\end{array}$ & $\begin{array}{l}.32 * * * \\
(\mathrm{n}=18537)\end{array}$ \\
\hline \multirow{8}{*}{$\begin{array}{l}\text { Old Member } \\
\text { States }\end{array}$} & Level of information & $0.06 * * *$ & $0.07 * * *$ & $.23 * * *$ & $.15^{* * *}$ \\
\hline & EU info source - TV & $0.05 * * *$ & $0.04 * * *$ & $0.08 * * *$ & $0.3^{* * *}$ \\
\hline & Trust \& democracy & $0.34 * * *$ & $0.38 * * *$ & $0.02 * *$ & $.46 * * *$ \\
\hline & Evaluation of national economy & -0.006 & $0.14 * * *$ & $0.03 * *$ & $-.03 * * *$ \\
\hline & Evaluation of European economy & $.10 * * *$ & $0.07 * * *$ & $0.15 * * *$ & $0.12 * * *$ \\
\hline & Age & $0.09 * * *$ & $0.05^{* * *}$ & $-0.03 * * *$ & -0.003 \\
\hline & Political view (Left/Right) & $-0.05 * * *$ & $-0.02 * *$ & n.a & 0.00 \\
\hline & Education & $0.06 * * *$ & $0.03 * * *$ & $0.03 * *$ & $0.04 * * *$ \\
\hline
\end{tabular}




\begin{tabular}{|c|c|c|c|c|c|}
\hline \multirow{9}{*}{$\begin{array}{l}\text { New Member } \\
\text { States }\end{array}$} & R Square & $\begin{array}{l}0.06 * * * \\
(n=3620)\end{array}$ & $\begin{array}{l}.12 * * * \\
(\mathrm{n}=2712)\end{array}$ & $\begin{array}{l}.13 * * * \\
(\mathrm{n}=4623)\end{array}$ & $\begin{array}{l}40 * * * \\
(n=4376)\end{array}$ \\
\hline & Level of information & $0.09 * * *$ & $0.06 * *$ & $0.22 * * *$ & $0.16 * * *$ \\
\hline & EU info source - TV & $0.04 *$ & 0.008 & $0.08 * * *$ & $0.05^{* * *}$ \\
\hline & Trust \& democracy & $.16 * * *$ & $0.30 * * *$ & 0.03 & $0.47 * * *$ \\
\hline & Evaluation of national economy & -0.01 & $0.06 * * *$ & $0.01 * * *$ & $0.06 * * *$ \\
\hline & Evaluation of European economy & $0.06 * * *$ & 0.01 & $.15 * * *$ & $0.12 * * *$ \\
\hline & Age & $.12 * * *$ & 0.03 & $-0.05^{* * *}$ & $-0.04 * * *$ \\
\hline & Political view (Left/Right) & 0.01 & 0.009 & n.a & 0.00 \\
\hline & Education & -0.02 & 0.03 & -0.005 & 0.01 \\
\hline
\end{tabular}

Note: Significance level of each variable $* *<0.05 ; * * *<0.001$. Dependent variable: level of attachment

The second hypothesis had assumed a negative relationship between specific support indicators and European identity especially after the Eurozone crisis. The hypothesis stemmed from the assumption that people support a given polity based on the associated costs and benefits. As such, it was argued that the Eurozone crisis had altered the existing beneficial relationship, subsequently affecting political support. The results presented in Table 2 do not, however, entirely support this view. In fact, these results indicate two very important points about specific support and European identity: the first is that there was a positive relationship between people's evaluations of the European economy and their sense of European identity among both the old and the new member states. In contrast, the second finding suggests that assessments of the national economy did not greatly alter the sense of attachment to a European identity. Returning to the hypothesis, we find that only the results of the 2014 national economic evaluation revealed a small but significant negative relationship with European identity among the old member states. For the remaining time, both indicators were positively associated with a feeling of attachment to the EU. Overall, then, these results reinforce the importance of economic growth for the development of a sense of identity in this political community.

The third hypothesis had aimed to test the association between perceived levels of democracy and trust and a sense of European identity. As expected, the relationship between these indicators of diffuse political support was positive and significant. While the results showed that this relationship weakened in 2013 for both EU groups, in 2014, both democracy and trust saw their stongest (positive) correlation with the dependent variable throughout the observed timespan. 
As regards the media effects hypothesis, the assumption had been that the receipt of information via TV led to cynicism about the polity and a subsequent malaise effect. Moreover, it was proposed that the malaise effect had been amplified during the Eurozone crisis; in other words, not only was there a negative relationship between obtaining information through TV and a feeling of attachment to the EU, but that this negative association grew stronger after the crisis. The results, however, did not support this assumption. Indeed, these findings revealed a fairly minor but still significant positive relationship between people's TV consumption and sense of European identity. Rather than affirming the malaise effect, then, the results endorsed the fifth hypothesis, indicating that relying on TV for information about European politics does not make people cynical. Instead, it makes them feel more attached to the EU.

\section{Conclusions}

Two concepts have been the primary focus of this study: the framework for political support and the different effects of the media on political support. To this end, I have adopted David Easton's notion of political support and applied my own and Fuch's (2011) modifications to align it with the mandate of this investigation.

As a next step, I performed a secondary data analysis using Eurobarometer surveys from 2005, 2006, 2013 and 2014. The results of this analysis yielded some important insights. The first of these was that the Eurozone crisis affected political support for the EU, thus pointing to the significance of the economic benefits that countries derive from EU membership. At the same time, however, the results revealed the marked dependence of collective EU identity on the existence of satisfaction with democracy and trust in the EU. This implies that people's relationship with the EU is not simply based on a costs-and-benefits analysis; rather, they expect the Union to be democractic and trustworthy (Schäfer - Weber 2014).

The main goal of this study has been to understand the effects of the media on European identity, attending to both the possibilities of media malaise and mobilisation. The results of my regression analysis corresponded with those of numerous studies that have found that media consumption is not linked with malaise effects (Norris 1996; Newton 1999,;Bennett - Rhine; Flickinger - Bennett 1999; Strömbäck - Shehata 2010).

To the contrary, my findings revealed a strong mobilisation effect. This allows for the deduction that the more an individual relies on the media as a source of political information, the more politically savvy they will become. Consequestly, they will adjust their attachment to a given political entity based on the information they receive about it. Drawing on all these findings, the following table provides an overview of the hypotheses that have been confirmed or rejected by this research. 


\begin{tabular}{|l|l|l|}
\hline Hypothesis & Confirmed & Rejected \\
\hline $\begin{array}{l}\text { H1: The level of all diffuse political support indicators declined after the } \\
\text { Eurozone crisis for both member states groups }\end{array}$ & $\bullet$ & \\
\hline $\begin{array}{l}\text { H2: Specific support indicators had a negative relationship with identity } \\
\text { across both old and new member states after the Eurozone crisis }\end{array}$ & & \\
\hline $\begin{array}{l}\text { H3: Democracy and trust have a positive impact on European } \\
\text { identity }\end{array}$ & $\bullet$ \\
\hline $\begin{array}{l}\text { H4: Using TV as an information source has a negative effect on European } \\
\text { identity. }\end{array}$ & & \\
\hline $\begin{array}{l}\text { H5: The scope of information accessed through media consumption has a } \\
\text { positive effect on European identity }\end{array}$ & $\bullet$ & \\
\hline
\end{tabular}

\section{Limitations}

It is necessary here to acknowledge the limitations of the present study, the most important of which concerns the dependent variable. Specifically, the literature on European identity includes one school of thought that posits that "attachment" might not be exactly the same thing as "identity" (see, e.g., Bruter 2008). I agree partially agree with this position, however given that this approach is common in empirical analyses of European identity (Schäfer - Weber 2014; Westle 2012), I would maintain that identity and attachment are conceptually close to one another. Additionally, some scholars have agreed that the malaise effect is not easily detectable and that where it does exist, its impact is minimal (Wolling 1999) and can be detected by analysing media content (Newton 1999). The current study, on the other hand, is concerned with media consumption as a predictor of malaise, and this may be one reason why the results do not indicate the presence of any such effect.

All in all, this study adds to the existing literature concerning the effects of the media on political attitudes. It concludes that media consumption has a mobilising rather than a malaise effect on political support, especially when it comes to feelings of identification with a particular collective. This work also establishes that as time passes, people are becoming better informed about European politics and lending their support to the EU based on both economic gains and normative ideals. As far as the malaise effect is concerned, my research joins the existing body of literature that argues that media consumption does not make people cynical (Norris 1996; Newton 1999) and that even where malaise exists, it usually has a very minimal influence on political attitudes (Wolling 1999). For a better understanding of the malaise effect, I would recommend 
undertaking further research on both media consumption and media content. One way of doing this would be to combine an analysis of specific media content with a survey of the frequency of this content's consumption by way of particular media. This approach would help determine whether the malaise effect can be seen in media content or media consumption or both. The recent Brexit decision of the UK public may offer a context for the investigation of how different pro- and anti-EU media content can change the direction of political support. Such research could explore the impact of media-induced malaise and/or mobilisation on feelings of Europeaness in greater detail and clarity.

\section{References}

Beaudonnet, L. and Danilo, D.M. (2012): Support for Europe: Assessing the complexity of individual attitudes, European Integration online Papers 16(2).

Bruch, A. and Pfister, E. (2014): What Europeans Saw of Europe: Medial Construction of European Identity in Information Films and Newsreels in the 1950s, Journal of Contemporary European Research 10(1): 26-43.

Earl Bennett, S., Rhine, S.L., Flickinger, R.S. and Bennett, L.L.M. (1999): Video malaise revisited: Public trust in the media and government, The International Journal of Press/Politics, 4(4): 8-23. doi: 10.1177/1081180x9900400402.

Brubaker, R. and Cooper, F. (2000): Beyond "identity", Theory and Society 29: 1-47.

Bruter, M. (2005): Citizens of Europe? The emergence of a mass European identity. Basinstoke: Palgrave Macmillan.

Bruter, M. (2008): Legitimacy, Euroscepticism \& Identity in the European Union. Problems of Measurement, Modelling \& Paradoxical Patterns of Influence', Journal of Contemporary European Research 4(4): 273-285.

Curtice, J., Rűdiger, S.-B. and Schrott, P. (1998): Do the Media Matter?. In: Annual Meeting of the Mid-West Political Science Association. Chicago, USA, 23-25 April 1998.

De Vreese, C.H. and Boomgaarden, H.G. (2006): Media effects on public opinion about the enlargement of the European Union, JCMS: Journal of Common Market Studies 44(2): 419-436. doi: 10.1111/j.1468-5965.2006.00629.x.

Delanty, G. (2002): Models of European identity: Reconciling universalism and particularism, Perspectives on European Politics and Society 3(3): 345-359. doi: 10.1080/15705850208438841.

Easton, David (1965): A Framework for Political Analysis. Englewood Cliffs: Prentice-Hall.

Easton, David. (1975): A re-assessment of the concept of political support, British Journal of Political Science 5(04): 435. doi: 10.1017/s0007123400008309.

Eichenberg, R.C. and Dalton, R.J. (2007): Post-Maastricht blues: The transformation of citizen support for European integration, 1973-2004, Acta Politica 42(2-3): 128-152. doi: 10.1057/ palgrave.ap.5500182. 
European Union. (2015, May 13): From 6 to 28 members. Available at: http://ec.europa.eu/enlargement/policy/from-6-to-28-members/index_en.htm (19 April 2016).

Fuchs, D. (2011): Cultural Diversity, European Identity and Legitimacy of the EU: A Theoretical Framework, in Fuchs, D. and Klingemann, H.-D. (eds.) Cultural Diversity, European Identity and Legitimacy of the EU. Cheltenham: Edward Elgar Publishing Limited, pp. 27-57.

Georgiou, M. (2006): Diaspora, identity and the media: Diasporic transnationalism and mediated spacialities. Cresskill, NJ: Hampton Press.

Herrmann, R. and Brewer, M.B. (2004): Identities and Institutions: Becoming European in the EU, in Herrmann, R., Risse, T., and Brewer, M.B. (eds.) Transnational Identities. Becoming European in the EU. Lanham: Rowman \& Littlefield, pp. 1-22.

Hix, S. (2008): What's wrong with the European Union and how to fix it. Malden, MA: Polity Press. Holtz-Bacha, C. (1990): Videomalaise revisited: Media exposure and political alienation in west Germany, European Journal of Communication, 5(1), pp. 73-85. doi: 10.1177/0267323190005001005.

Hooghe, L. and Marks, G. (2004): Does Identity or Economic Rationality Drive Public Opinion on European Integration? Political Science and Politics 37(3): 415-420.

Hooghe, L. and Marks, G. (2005): Calculation, community and cues: Public opinion on European integration', European Union Politics 6(4): 419-443. doi: 10.1177/1465116505057816.

Klingemann, H.D. (1999): Mapping Political Support in the 1990s: A Global Analysis, in Norris, P. (ed.) Critical Citizens Global Support for Democratic Government. Oxford: Oxford University Press, pp. 48-73.

Lang, K. and Lang, G. (1966): The Mass Media and Voting, in Bernard, B. (ed.) Reader in Public Opinion and Communication. New York: Free Press.

Luce, E. (1993): Broadcasters speak out against free trade in TV shows, The Guardian, 8 October, pp. 1-17.

Maier, M.L. and Risse, T. (2003): Europeanization, collective identity and public discourses, SSRN Electronic Journal. doi: 10.2139/ssrn.1569059.

Majone, G. (1998): Europe's "democratic deficit": The question of standards, European Law Journal 4(1): 5-28. doi: 10.1111/1468-0386.00040.

McLaren, L.M. (2005): Identity, interests, and attitudes to European integration. Houndmills, Basingstoke, Hampshire: Palgrave Macmillan.

Meech, P. and Kilborn, R. (1992): Media and identity in a stateless nation: The case of Scotland, Media, Culture \& Society, 14(2), pp. 245-259. doi: 10.1177/016344392014002007.

Miller, A.H., Goldenberg, E.N. and Erbring, L. (1979): Type-set politics: Impact of newspapers on public confidence, American Political Science Review, 73(01), pp. 67-84. doi: 10.2307/1954731.

Morley, D. (2001): Belongings: Place, space and identity in a mediated world, European Journal of Cultural Studies 4(4): 425-448. doi: 10.1177/136754940100400404.

Newton, K. (1999): Mass media effects: Mobilization or media malaise?, British Journal of Political Science 29(4): 577-599. doi: 10.1017/s0007123499000289.

Norris, P. (1996): Does television erode social capital? A reply to Putnam, PS: Political Science and Politics, 29(3): 474. doi: 10.2307/420827. 
Norris, P. (1999): The Growth of Critical Citizens, in Norris, P. (ed.) Critical Citizens: Global Support for Democratic Governance. Oxford: Oxford University Press, pp. 18-46.

Norris, P. (2000): A Virtuous Circle? The Impact of Political Communications in Post-Industrial Democracies. Cambridge, MA: Cambridge University Press.

Maier, J. and Rittberger, B. (2008): Shifting Europe's boundaries: Mass media, public opinion and the enlargement of the EU, European Union Politics 9(2):243-267. doi: 10.1177/1465116508089087.

Müller, M., Reckling, T. and Weiß, A. (2014): Introduction - Communicating European Integration: A Historical Perspective, Journal of Contemporary European Research 10(1): 4-11.

Robinson, M.J. (1976): Public affairs television and the growth of political malaise: The case of "the selling of the pentagon", The American Political Science Review 70(2): 409. doi: $10.2307 / 1959647$.

Ruchet, O. (2011): Cultural diversity, European identity and legitimacy of the EU: A review of the debate, in Fuchs, D. and Klingemann, H.-D. (eds.) Cultural diversity, European identity and legitimacy of the EU. Cheltenham: Edward Elgar Publishing Limited, pp. 3-26.

Schäfer, C. and Weber, D. (2014): European Identity in Times of Crisis, ECPR Graduate Student Conference. Innsbruck.

Scharpf, F. (1999): Governing in Europe. 1st ed. Oxford: Oxford University Press.

Scharpf, F. (2009): Legitimacy in the multilevel European polity', European Political Science Review 1(2): 173.

Schlesinger, P. (1991): Media, state, and nation: Political violence and collective identities. London: Sage Publications.

Silverstone, R. (1999): Why study the media? Thousand Oaks, [Calif.]: SAGE Publications.

Strömbäck, J. and Shehata, A. (2010): Media malaise or a virtuous circle? Exploring the causal relationships between news media exposure, political news attention and political interest, European Journal of Political Research 49(5): 575-597. doi: 10.1111/j.1475-6765.2009.01913.x.

Strath, B. (2002): A European identity: To the historical limits of a concept, European Journal of Social Theory 5(4): 387-401. doi: 10.1177/136843102760513965.

Walkenhorst, H. (2008): Constructing the European identity - Trap or gap? European integration between Community-building and path-dependency. Limerick: University of Limerick.

Westle, B. (2012): Identification and trust - resources of support for the European Union, in Karolewski, I. and Kaina, V. (eds.) Advances in European Politics - Civic Resources and the Future of the European Union. Florence: Routledge, pp. 15-36.

Wolling, J. (1999): Politikverdrossenheit durch Massenmedien? Der Einfluss der Medien auf die Einstellungen der Bürger zur Politik. Opladen/Wiesbaden: Westdeutscher Verlag.

Waqas Ejaz. 2005-2009 studied Mass Communication in University of Punjab, Pakistan. 2010-2012 completed MA in Communication Studies from Technische Universität Ilmenau. Since 2013 working as research assistant and doctoral candidate in Technische Universität Ilmenau. The main area of investigation for the doctoral 
includes understanding relationship and effects of media on European identity and European politics. Empirical Media Research and Political Communication Department, Technical University of Ilmenau, Ehrenberg Street 29, 98693 Ilmenau Germany. E-Mails: mian-waqas.ejaz@tu-ilmenau.de. 